The Influence of Personality Traits and Demographic Factors on Social Entrepreneurship Start Up Intentions

Author(s): Joyce Koe Hwee Nga and Gomathi Shamuganathan

Source: Journal of Business Ethics, Vol. 95, No. 2 (August 2010), pp. 259-282

Published by: Springer

Stable URL: http://www.jstor.org/stable/40785086

Accessed: 31-10-2017 18:50 UTC

\title{
REFERENCES
}

Linked references are available on JSTOR for this article:

http://www.jstor.org/stable/40785086?seq=1\&cid=pdf-reference\#references_tab_contents You may need to $\log$ in to JSTOR to access the linked references.

JSTOR is a not-for-profit service that helps scholars, researchers, and students discover, use, and build upon a wide range of content in a trusted digital archive. We use information technology and tools to increase productivity and facilitate new forms of scholarship. For more information about JSTOR, please contact support@jstor.org.

Your use of the JSTOR archive indicates your acceptance of the Terms \& Conditions of Use, available at http://about.jstor.org/terms

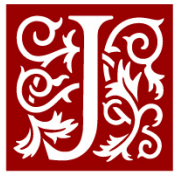

Springer is collaborating with JSTOR to digitize, preserve and extend access to Journal of Business Ethics

JSTOR 


\section{The Influence of Personality Traits and Demographic Factors on Social Entrepreneurship Start Up Intentions}

\author{
Joyce Koe Hwee Nga \\ Gomathi Shamuganathan
}

\begin{abstract}
The sheer impact of the recent global financial turmoil and scandals (such as Enron and WorldCom) has demonstrated that unbridled commercial entrepreneurs who are allowed to pursue their short-term opportunities regardless of the consequences has led to a massive depreciation of the wealth of nations, social livelihood and environmental degradation. This article suggests that the time has come for entrepreneurs to adopt a more integrative view of business that blends economic, social and environmental values. Social entrepreneurs present such a proposition through their deep commitment towards the social vision, appreciation of sustainable practices, innovativeness, ability to build social networks and also generate viable financial returns. It could be expected that social entrepreneurs often possess certain distinct personality characteristics which define their behaviours/actions. Personality traits are partly developed by innate nurturing, socialization and education. These tacit traits are also formed values/beliefs held and play an important role in driving social entrepreneurial decision making. Thus, personality traits may influence the intentions and the manner in which the individual acts. We hold that if social entrepreneurship is to be effective and impactful, business and management education can facilitate the development of these critical personality traits. Thus, this study primes at determining the personality traits that influence social entrepreneurs' start-up intentions. It also reinforces the findings that personality traits do influence entrepreneurship in general. This study examines the influence of the Big Five personality traits on social entrepreneurship dimensions. The findings reveal that agreeableness positively influences all dimensions of social entrepreneurship, whereas openness exerts a positive influence on social vision, innovation and financial returns. Methodologically, this study develops valid and reliable scales for social entrepreneurship and verifies the adopted Big Five personality measure of Schmit et al. (Pers Psychol 53:153-193, 2000) using the five-point Likert scale. The implication of this study is
\end{abstract}

that element of appreciation of social responsibility, sustainability and character development needs to be integrated within the business education curriculum to support social entrepreneurs in realizing genuine value and impact to the causes and communities they serve. Future business leaders also need to be equipped with entrepreneurship skills, while exuding independent and reflective thinking in the pursuit life-long learning. The originality of this study lies in its focus on personality traits on social rather than commercial entrepreneurship. It is hoped that the findings will trigger a paradigm shift towards greater social entrepreneurship through education by nurturing sustainable development values in future business graduates.

KEY WORDS: social entrepreneurship, personality traits, social responsibility, entrepreneurship education

\section{Introduction}

Entrepreneurship is often defined as the opportunistic pursuit of economic wealth via creative initiatives of the individual operating within an uncertain environment constrained by limited tangible resources (Austin et al., 2006; Mitchell et al., 2002). The framing of entrepreneurship within economic theory assumes the rationalistic model of man. Economic rationale neglects the idiosyncratic human capabilities that promote flexibility and use of social discretion in deriving practical innovative solutions (Baumol, 1968; Loasby, 2007). Economic theory also ignores the differences in human values, capabilities and power of the human will (Loasby, 2007). Past researchers have mostly focussed on commercial entrepreneurship with an emphasis of financial returns over social 
returns. Their reliance on the 'invisible hand' of the free-market system has placed the responsibility of safeguarding the public and social goods within the ambit of governments. The bureaucratic, political and inflexible nature of governments, however, have often rendered implementation of social policies ineffective (Dees, 2007). As a result, social entrepreneurs have often stepped to meet these gaps where governments have failed by emphasizing social value above financial returns (Haughton, 2008). The sheer impact of the recent global financial turmoil and scandals (such as Enron and WorldCom) has also demonstrated that commercial entrepreneurs who are let free to pursue their short-term opportunities regardless of the consequences has led to a massive depreciation of the wealth of nations, social livelihood and environmental degradation. This article suggests that the time has come for entrepreneurs to adopt a more integrative view of business that blends economic, social and environmental values. Social entrepreneurs also adopt a wider viewpoint on value creation compared to their commercial counterparts. They uphold the synergistic derivation of social, economic and environmental values without overemphasis on shareholders' wealth maximization (Kurucz et al., 2008).

Personality traits have been posited in explaining the industrious behaviours and agile actions of social entrepreneurs (Llewellyn and Wilson, 2003). Social entrepreneurs are often distinguished by their ability to envisage, engage, enable and enact transformational change efficiently in the face of scarce resources, risks and diverse contexts (Thompson, 2002; Thompson et al., 2000). However, the influence that personality traits play in defining social entrepreneurs has remained controversial and underexplored and under-researched.

This article endeavours to investigate the influence of the Big Five personality trait dimensions comprising openness, agreeableness, neuroticism and conscientiousness on social entrepreneurship. In light of the findings that the influence of personality traits is the highest in determining business start-up intentions in budding entrepreneurs, a sample of college and undergraduates has been employed (Frank et al., 2007). In addition, the sample consisting of business and management students from a private higher education institution (HEI) has also been selected in view of the implications of this study on the business education curriculum. The quantitative survey method is adopted as part of an initial investigation to obtain the macro view concerning the influence between personality traits and social entrepreneurship based on the conceptual framework developed for this study (Figure 1). Similar studies on commercial entrepreneurship have also adopted such quantitative survey methods (Table I). Implications are then derived by employing theoretical triangulation in drawing inferences from the findings of the study. The authors adopt a technical and situational paradigm stance which recognizes that quantitative and qualitative methods are interconnected but have distinctive epistemological and ontological assumptions (Bryman and Bell, 2007). Thus, while quantitative and qualitative methods are not compatible within the same phase of this study, qualitative methods can be employed to draw theoretical inferences and/or applied within different study situations and contexts (Flick, 2009; Miles and Huberman, 1994).

As such, this article starts by first reviewing the underpinning literature concerning the concept of social entrepreneurship and the Big Five model of personality traits (Costa and McCrae, 1992 cited in Llewellyn and Wilson, 2003) to understand their interconnections that form the basis for the development of the conceptual framework and hypotheses of this study. Second, measurement scales for social entrepreneurship dimensions, namely sustainability, vision, networking and returns orientation are developed from concepts derived from extant literature. The validity and reliability of social entrepreneurship dimensions as well as the Big Five personality trait measurement adapted from Schmit et al. (2000) are determined using Exploratory Factor Analysis (EFA) and Cronbach's $\alpha$, respectively. Third, hypotheses testing are conducted using the Multiple Linear Regression to substantiate the research questions. The study found that agreeableness positively influences all dimensions of social entrepreneurship, whereas openness exerts a positive influence on social vision, innovation and financial returns. These findings have important implications on the design of business education curriculum particularly in developing personality traits and values within future business leaders/entrepreneurs that will enable them to be transformative in integrating social, environmental and economic values. 


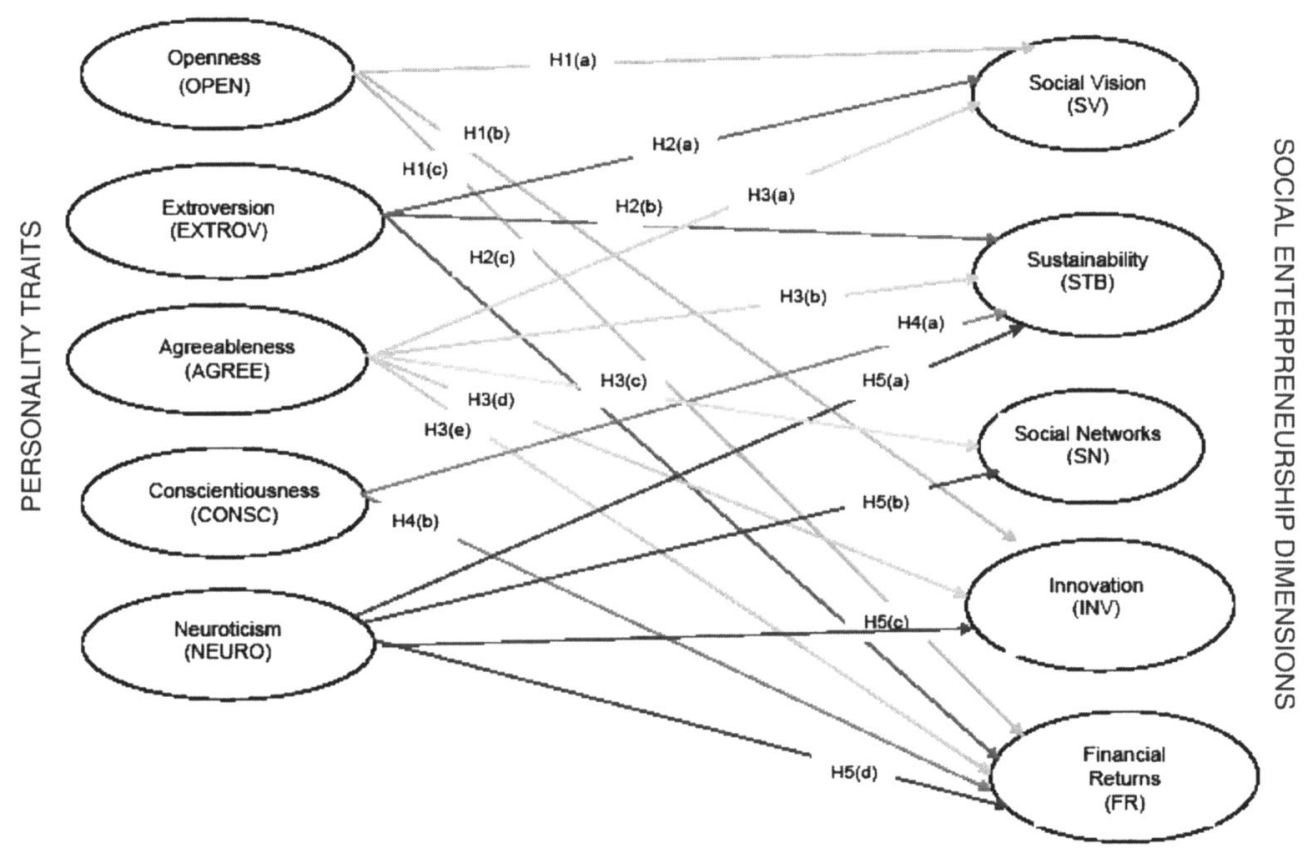

Figure 1. Conceptual framework.

We maintain that if social entrepreneurship is to be effective and impactful, business and management education can facilitate the development of these critical personality traits. Thus, this study primes at determining the personality traits that influence social entrepreneurs' start-up intentions. It also aims to reinforce the findings that personality traits do influence entrepreneurship in general.

\section{Theoretical background}

This section provides the theoretical underpinning surrounding the broad concepts of entrepreneurship and personality traits. It will then streamline the focus of this study to social entrepreneurship and Big Five personality traits and elaborate on their respective dimensions. The social entrepreneurship dimensions covered are social vision, sustainability, social networks, innovation and financial returns. The Big Five personality traits comprises openness, extroversion, agreeableness, conscientiousness and neuroticism.

\section{Overview of the field of entrepreneurship}

Entrepreneurship is a multi-dimensional discipline with roots spanning the fields of economics, psychology, sociology and strategic management (Mitchell et al., 2002). Entrepreneurial motivation represents the blending of social interaction, technical competence and emotional zeal of the individual (Goss, 2008). The definition of entrepreneurship remains broad. In general, the evolving definition of entrepreneurship involves individual(s) who are driven to act on opportunities and/or environmental catalysts by employing innovative processes in the face of limited resources (Handy et al., 2007; Mitchell et al., 2002; Schaper and Volery, 2004). Past research pertaining to entrepreneurship can be classified into three major genres, namely the functional, personality and behavioural approaches (Cope, 2005). The functional approach is linked to rational outcomes within economic theory. The personality approach concerns the characteristics of individual psychological traits that define an entrepreneur. Finally, the behavioural approach derives from strategic management and involves the process of how an entrepreneur perceives and acts on opportunities presented.

This study is positioned from the personality approach. Personality traits are predictable characteristics of individual behaviour which assist in explaining the differences of individual actions in similar situations (Llewellyn and Wilson, 2003). We adopt the stance that individual personality of social 


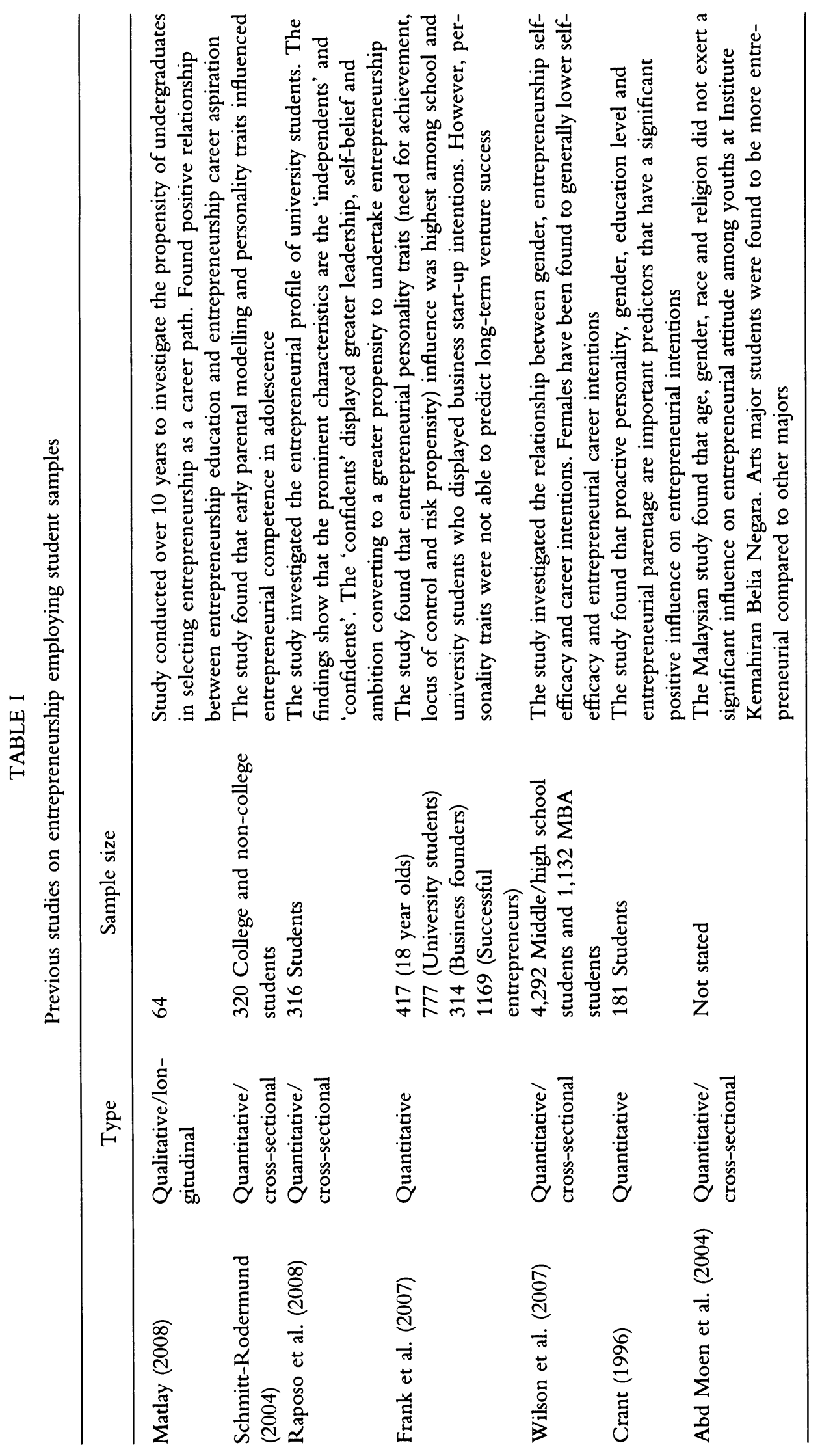


entrepreneurs provides the impetus to high willpower that drives their passions, innovativeness and social interactions. This sanctions their choice and ability to integrate social, environmental and economic aspects in the enhancement of value (Goss, 2005, 2008; Kurucz et al., 2008; Rhee and White, 2007).

Characteristics of social entrepreneurship (SOC_ENT) In contrast to commercial entrepreneurs, social entrepreneurs are committed to serve basic human needs and to facilitate impactful quality of life improvement within society (Austin et al., 2006; Elkington, 2006; Ridley-Duff, 2008). Social entrepreneurs fill the gaps in the provision of public goods where governments have failed and where the private sector views that the risk do not commensurate the rewards associated with such ventures (Haughton, 2002). Most cited characteristics of the social entrepreneurs as innovativeness, achievement centred, independence, sense of destiny, low risk aversion, tolerance for ambiguity and social value creation (Brooks, 2009). However, these highlighted aspects of social entrepreneurs' confuse innate characteristics with personality traits. This study focuses on four related aspects of social entrepreneurship, namely the social vision, sustainability, social networking, innovativeness and financial returns. Social vision encompasses the sense of destiny. Sustainability and financial return inclination covers the aspects of social value creation. Achievement orientation, independence, risk aversion and ambiguity tolerance relates to personality traits dimensions of conscientiousness and extroversion which are discussed in the next section.

Social entrepreneurship transcends philanthropic and/or charitable giving as it promotes a more enduring and engaging solution to social problems. Charitable giving is often one-off to appease the conscience or seeks to promote a favourable corporate image. However, it may not be effective in perpetuating social problems such as poverty as recipients often lag by shrugging off initiative and responsibility for progress (Dees, 2007). Social entrepreneurs promote their mission for social change by supporting the beneficiaries to realize their potential and undertake ownership in improving their quality of life (Elkington and Hartigan, 2008, p. 33). As such, social entrepreneurs adopt the enduring synergistic view of value creation by uncovering innovative ways where social, environmental and economic issues can be integrated and enhanced (Kurucz et al., 2008).

The social entrepreneurship process involves envisioning, engaging, enacting and enabling transformational change to promote social, economic and environmental or triple bottom line performance (Thompson, 2002; Thompson et al., 2000). Envisioning involves identifying a real social need that presents both a gap and opportunity. The social entrepreneur is committed to their social vision and will find pragmatic, innovative solutions to social problems regardless of ideological or resource constraints. The social entrepreneur is often unreasonably ostentatious in fulfilling their mission to create/ enhance social value (Elkington and Hartigan, 2008, p. 5). The engaging process involves demonstrating commitment through social networks to harness trust, transparency and credibility. Strategic partnerships are crucial in the not-for-profit sector to garner grass root support, participation and legitimization of the social mission (Gliedt and Parker, 2007). Social networks are also an avenue for emotional, financial and human resources. The enacting process involves leading, directing and assigning purpose to the vision from inception to fruition. The enabling process includes the acquiring of finance and training of human resources to sustain the social vision.

This study streamlines the characteristics of social entrepreneurs' into five dimensions, namely social vision, sustainability, social networking, innovativeness and financial returns. The following subsections details these further.

Social vision $(S V)$. The social entrepreneur is driven by a compelling social vision that encapsulates a strong sense of obligation and destiny towards fulfilling a basic human need (Barendsen and Gardner, 2004; Brooks, 2009). The social vision drives the ability to see opportunities beyond the present with the objective of extending the stewardship arm to be an agent of social change (Barendsen and Gardner, 2004; Dees, 2001; Keogh and Polonsky, 1998). Commitment for social issues is usually borne with a sense of emotional affection and sense of responsibility to sustain an environmental and/or social cause (Keogh and Polonsky, 1998). As such, social entrepreneurs often act as advocates in voicing and 
meeting gaps in social needs where governments and private enterprises lag (London, 2008). Traumatic events experienced in early childhood often act as catalysts in the development of beliefs of social entrepreneurs (Barendsen and Gardner, 2004). Combined with an enduring commitment, social entrepreneurs are not easily swayed by the pendulum of market forces in the quest towards social value creation.

Sustainability (STB). Sustainability is often triggered by an engaged state of social and moral critical consciousness that businesses and individuals exist as part of an interconnected inter-generational, enduring global ecosystem (Cartwright and Craig, 2006; Mustakova-Possardt, 1998; Savitz and Weber, 2006). Businesses can no longer elude that they are the major contributors towards social and environmental degradations. As such, they need to lead change through restorative economic practices (Hawken, 1992). Since biological resources are not substitutable as capital and labour are, businesses need to embrace natural capitalism whereby value is assessed by the integrated ecological and economical impacts (Lovins et al., 2007). This study advances the view that sustainable development via natural capitalism practices enhances the quality of life of society.

Sustainability complements the conventional economic wisdom with the commitment to do the right thing in improving the quality of human life by including the Earth and society as legitimate stakeholders (Shrivasta, 2000 in Cartwright and Craig, 2006; Hawken, 1992). As such, strategies towards sustainability are deeply entrenched within the value, culture and vision of the entrepreneur and/or organization as they are affectively and normatively grounded (Anderson, 1998; Keogh and Polonsky, 1998). By embracing sustainability, social entrepreneurs are determined to drive social change by serving the needs of greater numbers of people(s) including the bottom of the pyramid market which may not be feasible for commercial entrepreneurs and governments (Hart, 2005). Social value creation becomes an essential, integral component of shareholder wealth maximization to social entrepreneurs.

The quest towards sustainability requires congruency in the strategic management of the environment, values and resources (Thompson, 1998). The dexterity of the entrepreneur in properly aligning opportunities, vision and culture within the social networks and actual available capabilities/competencies resources promotes organizational learning that stimulates desire for social change. They then orchestrate further transformational change through stewardship in harmonizing the legitimate economic, social and environmental concerns (Molteni, 2006; Robins, 2006). Sustainability practices adopt entrenched responsibility and unity of purpose in judgements aimed at promoting stakeholder accountability aimed at deriving triple bottom line performance (Mort et al., 2003).

In contrast with corporate philanthropy which often involves targeted shorter term giving linked to firms' commercial interests, reciprocal strategic economic returns and reputational benefits, social entrepreneurship strives at providing solutions that enhances social value through long-term sustenance of quality of life and ecological balance (Leisinger, 2007; Machan, 1999). Social entrepreneurs emphasize human life as part of an interdependent, living ecosystem. As such, any action undertaken needs to be guided by authentic values, principles and commitment to preserve and protect the long-term survival and rights of the community and environment. By doing so, social entrepreneurs seek to create enduring social value and to promote the betterment of humankind through the dedication towards continuous, responsible innovations (Machan, 1999).

Social networks $(S N)$. Social capital theory suggests that social capital exist in three dimensions, namely structural, relational and cognitive (Nahapiet and Ghoshal, 1998). This study holds that social networks (formal and/or informal) form an invaluable resource to social entrepreneurs for advice, human resources, innovative ideas/capabilities, financial and emotional support (Greve and Salaff, 2003; Nahapiet and Ghoshal, 1998).

From the structural perspective, social networks provide a system whereby the mission of the entrepreneur is embedded and disseminated. Network ties enable a rich sharing of information and knowledge to create more innovative and relevant solutions to service the benefit of the wider community (Chen and Wang, 2008; Nahapiet and Ghoshal, 1998; Shaw and Carter, 2007; Thompson and Doherty, 2006). Personal social network ties established also bridges the information asymmetry 
between the entrepreneur and the potential investors (Shane and Cable, 2002).

The relational perspective posits that active participation in networks induces collective learning and fosters better understanding of social community norms. Trust is developed through a dynamic process of open communication and renegotiations between stakeholders. Hence, credibility of social endeavours is enhanced through the identification of fit between opportunities and the social need (Shaw and Carter, 2007). Trust has been found to moderate the relationship between social networking and innovation (Chen and Wang, 2008). Social networks evolve through the motivation, planning and contracting stages (Greve and Salaff, 2003). The highest level of communication occurs at the planning phase. At the initial stages, networking is mostly associated with parties closest to the entrepreneur. This sets the momentum for longer term working relationships that allows time for mutual assessment of personal motivations and commitments of participants resulting in the development of social reputational capital. Social entrepreneurs often rely on personal contacts and past experience to build support for their mission and risk losing their credibility if their venture fails (Shaw and Carter, 2007). Reputation plays an important mediating role and constitutes a non-substitutable social resource in contracting, networking and the survival of the social enterprise (Schaper and Volery, 2004, pp. 6465; Shane and Cable, 2002).

Finally, the cognitive dimension concerns the derivation of shared meanings in particular contexts (London, 2008; Nahapiet and Ghoshal, 1998). Trust and credibility deepens as the shared meanings are entrenched within tacit personal values and beliefs further strengthening bonds of the network participants (De Carolis and Saparito, 2006). The unity towards a common purpose achieved through local enterprise networks comprising entrepreneurs, investors, community, NGOs and governments in developing countries has been found to facilitate the generation of sustainable outcomes (Wheeler et al., 2005). The proximity to the context also allows these networks to develop native capabilities, coordinate resources and share knowledge thereby maximizing their long-term impact in enhancing the quality of life and economic development. Native capabilities also promote practical local solutions to real problems further developing trust and social capital. This forms an important aspect of competitive advantage for social entrepreneurs (Hart and London, 2005).

Innovation (INV). Encumbered by uncertainty, endowed with limited resources and driven by an unwavering passion to be an agent of social change, social entrepreneurs need to be agile and creative in shaping collective social solutions (Dees, 2001; Elkington and Hartigan, 2008, pp. 85-133; Shaw and Carter, 2007). Social innovation unlocks value by creating a platform for sustainable solutions through a synergistic combination of capabilities, products, processes and technology (Auersweld, 2009; Phills et al., 2008). The motivation to be an agent of social change may go against the grain of rational and traditional economic thoughts and pose as a force for 'creative destruction' to unlock value (Hart, 2005; Jayasinghe et al., 2008; Schumpeter, 1971 cited in Pittaway, 2005).

Innovative capabilities are enhanced as individuals develop personal mastery throughout the networking process involving combination and exchange of intellectual and social capital (Littunen, 2000; Nahapiet and Ghoshal. 1998). From the social entrepreneurs perspective, this includes exploring ways to penetrate unconventional 'bottom of the pyramid markets'. These markets have been neglected by commercial entrepreneurs due to the perceived high risk that do not justify economic returns (Hart, 2005). Innovative processes and technologies are employed by social entrepreneurs to create a social and strategic fit for products and services to tap into these underdeveloped, unchartered markets (Hart and Christensen, 1992; Pralahad 2006, pp. 25-27). A more sustainable socio-economic development is achieved as these innovative initiatives gradually empower these underprivileged markets to participate in the activities of mainstream markets.

Financial returns (FR). The financial perspective originates from the demand side view which holds that entrepreneurs need to seize opportunities and compete for scarce resources to generate economic returns. The economic perspective upholds the shareholder primacy viewpoint whereby the role of the entrepreneur as an agent to the principal is limited to the maximization of financial wealth. 
Outcomes are quantifiable in terms of profitability metrics. The 'invisible hand' of free markets is assumed to be able to produce an efficient outcome and absolves the responsibility of the entrepreneur from addressing social outcomes (Friedman, 2004 in Schaefer, 2008). In a less than perfect reality, the public good problem is not efficiently addressed by a single firm and often left to governments for resolution.

Proponents of the economic view adopt the view that human nature is rational and self-interested. They discount the individual ability to initiate free will and exercise choice (Baumol, 1968; Machan, 1999). The assumption of a perfectly laissez-faire economy capable of producing a morally justifiable outcome is far reaching. The rationale of mechanistic individuals devoid of morals, emotions and practical reasoning is a fallacy. As such, a purely economic view would exclude emphasis on subjective, intangible non-financial (for example social and environmental) and moral outcomes of social responsibility (Schaefer, 2008).

In practice, social entrepreneurship inclines towards stakeholder theory that seeks to bridge the gap in the provision of the public good where governments are unable to and/or where the commercial viability defies capabilities of corporations (Haughton, 2008). Social entrepreneurship manifests in a continuum of business models ranging from leveraged non-profit ventures, hybrid ventures to social businesses (Elkington and Hartigan, 2008; Haughton, 2008). Leveraged non-profits often rely on availability of private funding in serving a basic human need driven by an enlightened social vision. Hybrid ventures partially recover their costs through profits generated from goods and services (Pralahad, 2006). Hybrid ventures may also rely on grants from governments and corporations. The pricing mechanism adopted may be based on an equitable 'pay as you can afford' system, for example, in the case of Aravind Eye Hospital, India. In contrast, social businesses are set up as for profit ventures. However, they differ from commercial ventures in that they emphasize social returns as well as financial returns. Shareholders may receive a return of their initial investment but are not paid dividends (Yunus, 2007, pp. 21-40). Profits are reinvested in the business to serve social policy initiatives (Gunn et al., 2008), for example, micro-financing by Grameen Bank.
Social entrepreneurs pursue a variety of social causes requiring high levels of willpower, innovativeness, social interaction and sanctioning (Goss, 2005, 2008; Rhee and White, 2007). This study adopts the stand that personality traits play an important role in moulding the individual's perceptions and behaviours which are instrumental in driving the social mission and legitimacy of the enterprise. The following section discusses the Big Five personality traits factors that entrepreneurs are likely to possess.

\section{Personality traits}

Personality traits are enduring, predictable characteristics of individual behaviour that explain differences in individual actions in similar situations (Llewellyn and Wilson, 2003). Personality traits may be influenced by the unique, tacit, subjective personal knowledge, values/beliefs, perception and experiences of the individual that are not easily replicated (Kor et al., 2007). Personality traits of an individual may serve as a catalyst which influences the risk perception of entrepreneurs in decision making (Chaucin et al., 2007; Naffziger et al., 1994; Rauch and Frese, 2007). Proactive personality have been found to be a significant predictor especially of entrepreneurial start-up intentions, but the influence reduces in time as the venture maturates (Crant, 1996; Frank et al., 2007). Entrepreneurs have been found to possess higher scores of tolerance for ambiguity, internal locus of control, proactive personality, self-efficacy and need for achievement compared with non-entrepreneurs in explaining business success (Cools and Van Den Broeck, 2008; Crant, 1996; D'Intino et al., 2007; Ong and Ismail, 2008; Rauch and Frese, 2007). Most studies involving the relationship between personality traits on entrepreneurship and in organizational settings yielded inconclusive findings (Abu Elanain, 2008; Ong and Ismail, 2008). This study attempts to fill the lacuna in studies investigating the influence of the Big Five personality trait dimensions on social entrepreneurship (Costa and McCrae, 1992 cited in Llewellyn and Wilson, 2003). The following section discusses the Big Five traits, namely openness, extroversion, agreeableness, conscientiousness and neuroticism. 


\section{Openness (OPEN)}

Openness is manifested in a liberal value system where individual intellectual curiosity and affinity towards novelty of new experiences are welcomed (McCrae and Costa, 1986 cited in Abu Elanain, 2008). Individuals who are high on the openness dimension are not afraid of new challenges, versatile, imaginative and often display high degree of creativity (Yong, 2007, pp. 29-30; Llewellyn and Wilson, 2003). However, they may appear to be impulsive, overly inquisitive and may be easily bored with status quo. As such, they are often misunderstood by others for their individualistic nature. Entrepreneurs have been found to have greater openness compared to administrative personnel due to their need to be creative in the utilization of scarce resources (Nordvik and Brovold, 1998). Openness has also been found to positively influence citizenship behaviour (Abu Elanain, 2008). However, openness is found to be negatively related to the long-term sustainability of a business venture (Ciavarella et al., 2004). As social entrepreneurship is a relatively new field that may require individuals to go against conventional economic wisdom to create social value, the following hypotheses are posited:

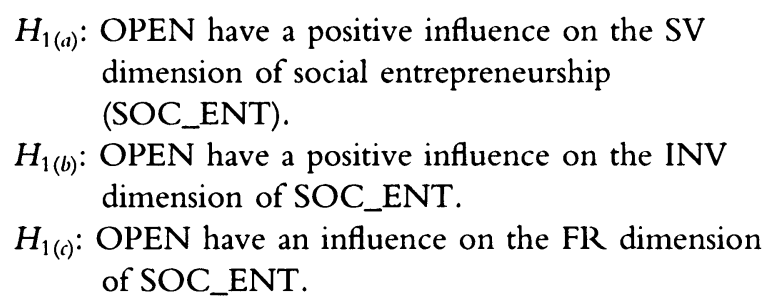

\section{Extroversion (EXTROV)}

Extroverted individuals are exemplified by sociable, outgoing, positive attitude and assertive characteristics (Ciavarella et al., 2004; Llewellyn and Wilson, 2003; Moon et al., 2008; Yong, 2007, p. 8). Extroversion contributes towards the proactive personality required in fuelling the instinct and driving the charismatic vision of the social entrepreneur (Crant, 1996). Social entrepreneurs are expected to possess extroversion as they have to be willing and able to communicate well with a myriad of stakeholders. Extroversion also creates a positive perceived locus of control as they are driven to fulfil their risk-taking propensity and need for achievement (McCarthy,
2003). Entrepreneurs have been found to possess higher extroversion than administrative workers (Nordvik and Brovold, 1998), and this assertiveness positively influences entrepreneurial success (Caliendo and Kritikos, 2008). However, a detailed analysis of extroversion characteristics comprising reward sensitivity, sociability and positive emotions was found to off-set one another (Ciavarella et al., 2004; Moon et al., 2008; Zhao and Seibert, 2006). This may explain why many studies investigating the overall effect of extroversion on citizenship behaviour and entrepreneurship remain inconclusive. As social entrepreneurs are perceived to be led by their strong, albeit 'unreasonable' drive to achieve social mission through social businesses, the following hypotheses are posited:

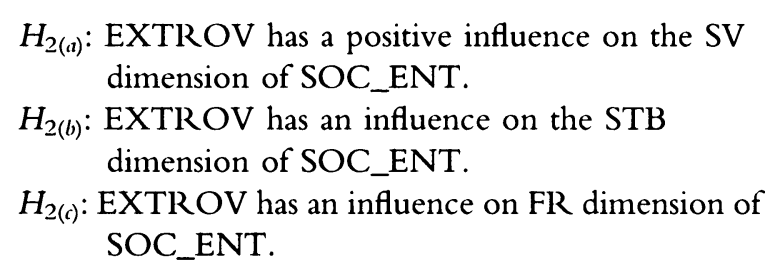

\section{Agreeableness (AGREE)}

Agreeableness concerns the ability to foster social consensus while upholding mutual understanding and trust (Llewellyn and Wilson, 2003; Yong, 2007, p. 30). Agreeableness in interpersonal relationships includes the ability to be good listeners, patient, empathize and promoting harmony in social interactions (Caliendo and Kritikos, 2008). Trusting and co-operative environments establish good rapport in alliances which facilitates exchange of technologies and raising capital for growth (Ciavarella et al., 2004). Nonetheless, overly agreeable individual characteristics may lead to compromise to gain acceptance of others and lower risk-taking propensity for unpopular ventures. The following hypotheses are posited.

\footnotetext{
$H_{3(n)}$ : AGREE has a positive influence on the SV dimension of SOC_ENT.

$H_{3(b)}$ : AGREE has an influence on the INV dimension of SOC_ENT.

$H_{3(c)}$ : AGREE has an influence on the $\mathrm{SN}$ dimension of SOC_ENT.

$H_{3(\infty)}$ : AGREE has an influence on the STB dimension of SOC_ENT.;

$H_{3(e)}$ : AGREE has an influence on FR dimension of SOC_ENT.
} 


\section{Conscientiousness (CONSC)}

The conscientious trait relates to an individual's meticulousness, conformance with rules/procedures and the incessant obsession in maintaining high standards of performance (Llewellyn and Wilson, 2003; Yong, 2007, p. 32). Conscientious individuals are driven by a strong sense of responsibility, industriousness and need for achievement which promotes their dependability at work (Ciavarella et al., 2004). Need for achievement has been found to positively related to competitive advantage of the firm (Ong and Ismail, 2008). Conscientiousness has also been positively linked to long-term survival of a business venture (Ciavarella et al., 2004). As such the following hypotheses are posited.

$$
\begin{aligned}
H_{4(n)}: & \text { CONSC has an influence on the STB dimension } \\
& \text { of SOC_ENT. } \\
H_{4(b)} \text { : CONSC has an influence on FR dimension of } & \text { SOC_ENT. }
\end{aligned}
$$

\section{Neuroticism (NEURO)}

Neuroticism is the degree of emotional stability of the individual (Yong, 2007, p. 9; Llewellyn and Wilson, 2003). Individuals who are highly neurotic often display mood swings, impulsiveness, self-consciousness, low self-esteem and depression (Costa and McCrae, 1992 cited in Zhao and Seibert, 2006). In contrast, entrepreneurs who are constantly challenged by diversity of complex situations involving management of scarce resources in tandem with pressures of illuminating legitimacy in the face of pressures from stakeholders need to exhibit high degree of optimism and emotional intelligence (Crane and Crane, 2007; D'Intino et al., 2007). As such, low neuroticism scores are expected. Thus, the following hypotheses are posited:

\footnotetext{
$H_{5(a)}$ : NEURO has an influence on the STB dimension of SOC_ENT.

$H_{5(b)}:$ NEURO has an influence on the $\mathrm{SN}$ dimension of SOC_ENT.

$H_{5(r)}$ : NEURO has an influence on the INV dimension of SOC_ENT.

$H_{5(n)}$ : NEURO has an influence on FR dimension of SOC_ENT.
}

\section{Social desirability bias}

Social desirability bias (SDB) concerns the tendency of individuals to over-claim or present themselves in a favourable manner (King and Brunner, 2000). SDB is especially prevalent in self-report measures tapping into values and perceptions that are considered socially sensitive and/or undesirable research. While eliminating SDB in total is not possible, there are methods to reduce the occurrence (Randall and Fernandes, 1991). Measures include phrasing questions in a nonthreatening manner using familiar terms, obtaining prior informed consent and through assurance of anonymity (Andanda, 2005; Homan, 2001; Vinten, 1997). In addition, wording of questions seeking a 'third party' view may encourage individuals to divulge their view more freely behind the facade of impersonality. Nonetheless, SDB in desirable values increase rather than contaminate the validity of responses (Sarros et al., 2006). This is because individuals may feel greater ease and less threatened to accentuate positive traits or aspects of actions. This study has addressed and taken the necessary precautions to reduce SDB. The Strahan-Gerbasi Social Desirability Scale (1972 cited in Thompson and Phua, 2005) has been included to assess SDB.

The conceptual framework of this study to investigate the influence of the Big Five personality factors on social entrepreneurship dimensions is illustrated in Figure 1.

\section{Methodology}

The authors adopt a technical and situational paradigm stance which recognizes that quantitative and qualitative methods are interconnected but have distinctive epistemological and ontological assumptions (Bryman and Bell, 2007). As such quantitative and qualitative methods are not compatible within the same phase of this study. However, qualitative methods can complement quantitative findings by drawing of theoretical inferences and/or applied within different study situations and contexts in future studies (Flick, 2009; Miles and Huberman, 1994).

This section describes the methodology used in the main study which adopts the quantitative survey method as part of an initial empirical investigation to obtain the macro view concerning the influence between personality traits and social entrepreneurship. The hypotheses within the conceptual framework developed for this study (Figure 1) were derived from 
review of extant literature in the previous section. Similar studies on commercial entrepreneurship have also often adopted the quantitative methodology to test hypotheses triangulated from extant literature and/or previous qualitative study propositions (Table I).

The following section also describes the sampling design, measurement assessment and methods used for data analysis. The section starts by elucidating why a sample of students is selected as well as elaborates on the scales used for the quantitative survey conducted. It then elaborates on the empirical tests used to test the hypotheses developed for this study based on the conceptual framework in Figure 1 above. The statistical package used for this study was SPSS 16 .

\section{Sampling design}

As the purpose of the study is to investigate the theoretical rather than population generalizability of the conceptual model posited in Figure 1, a purposive judgemental sampling design is utilized (Cavana et al., 2000, p. 263). The sample comprised college students and undergraduates from private HEI as they form the future human capital and leaders in nation development. Although there is no prior specific study relating to social entrepreneurship in Malaysia, student samples have often been utilized in entrepreneurship studies as shown in Table I. Of a total of 200 survey questionnaires were administered on individual students, 181 were returned/completed and used for data analysis.

\section{Measurement assessment}

The questionnaire for social entrepreneurship dimensions was developed based on the concepts derived from extant literature forming a methodological contribution of this study. As for personality traits, the Big Five personality measures advanced by Schmit et al. (2000) are adopted and adapted for the context of this study. A five-point Likert scale is employed for the abovementioned constructs.

\section{Reliability}

Reliability or internal consistency of the items within each construct of this study is assessed by observing the Cronbach $\propto$ (Cavana et al., 2000, p. 211). As this study forms a preliminary research into social entrepreneurship, the Cronbach $\alpha$ of 0.60 and above will be considered to be reliable (Hair et al., 2006, pp. 137-139; Nunnally, 1967 p. 226 cited in Peterson, 1994).

\section{Validity}

There is many genres of validity, namely, face, content and construct validities (Cavana et al., 2000, pp. 212-215). Face and content validities are assessed by an extant review and verification from literature as well as obtaining independent expert review. Construct validity comprising convergent and discriminant validities of the measurements for social entrepreneurship and personality traits constructs is evaluated via EFA using the Principal Components Method. As the items making up the constructs of this study are likely to be correlated, the Direct Oblimin factor rotation method is employed. In line with the sample size of between 150 and 200, factor loadings of 0.45 and above is considered significant (Hair et al., 2006, p. 128).

\section{Data analysis}

Hypotheses $H_{1}$ to $H_{5}$ series are tested by engaging the Multiple Linear Regression (MLR) method. The relevant social entrepreneurship (SOC_ENT) dimensions are the dependent variables (SV, STB, $\mathrm{SN}$ and INV respectively) and the personality trait variables (OPEN, EXTROV, AGREE, CONC and NEURO) as the independent variables. In adopting the $95 \%$ confidence interval, the hypothesis will be considered significant if the $p$-value is below 0.05 .

\section{Findings}

\section{Descriptive statistics}

The sample of this study comprise a total of 181 respondents comprising students from private $\mathrm{HEI}$ in Klang Valley, Malaysia. Table II displays the sample demographic characteristics of the respondents. In terms of age, the respondents have been found to be 
TABLE II

Descriptive statistics

\begin{tabular}{|c|c|c|c|c|}
\hline & Frequency & Percent & Valid percent & Cumulative percent \\
\hline \multicolumn{5}{|l|}{ Age } \\
\hline 20 and below & 92 & 50.8 & 51.1 & 51.1 \\
\hline $21-23$ & 86 & 47.5 & 47.8 & 98.9 \\
\hline $24-26$ & 2 & 1.1 & 1.1 & 100 \\
\hline Total & 180 & 99.4 & 100 & \\
\hline Missing system & 1 & 0.6 & & \\
\hline Total & 181 & 100 & & \\
\hline \multicolumn{5}{|l|}{ Race } \\
\hline Malay & 3 & 1.7 & 1.7 & 1.7 \\
\hline Chinese & 170 & 93.9 & 94.4 & 96.1 \\
\hline Indian & 3 & 1.7 & 1.7 & 97.8 \\
\hline Others & 4 & 2.2 & 2.2 & 100 \\
\hline Total & 180 & 99.4 & 100 & \\
\hline Missing system & 1 & 0.6 & & \\
\hline Total & 181 & 100 & & \\
\hline \multicolumn{5}{|l|}{ EDUC_LVL } \\
\hline Foundation studies & 86 & 47.6 & 48.3 & 48.3 \\
\hline Diploma & 6 & 3.3 & 3.4 & 51.7 \\
\hline Undergraduate degree & 82 & 45.3 & 46.1 & 97.8 \\
\hline Others & 4 & 2.2 & 2.2 & 100 \\
\hline Total & 178 & 98.3 & 100 & \\
\hline Missing system & 3 & 1.7 & & \\
\hline Total & 181 & 100 & 100 & \\
\hline
\end{tabular}

almost evenly distributed between the categories of below 20 (51.1\%) and between 21 and 23 (47.8\%). The majority race is Chinese and mostly pursuing foundation studies $(47.6 \%)$ or undergraduate degrees $(45.3 \%)$.

\section{Measurement assessment}

Tables III and IV represent the final pattern matrix results of the EFA for the Big Five personality factors and social entrepreneurship dimensions, respectively. Based on Table III, the final pattern matrix for the Big Five personality factors was 0.77 for agreeableness and extroversion, 0.69 for neuroticism, 0.73 for openness and 0.75 for conscientiousness. Since the Cronbach $\alpha$ values were between 0.60 and 0.70 with less than 10 items constituting each of the constructs, the reliability of the scale has been established (Hair et al., 2006, pp. 137-139). The Kaiser-Meyer-Olkin test (KMO) shows a figure of 0.77 and the Bartlett's test returns a chi-squared value of 1,364 $(\mathrm{df}=253 ; p=0.01)$ indicating that good sampling adequacy and the assumption of non-identity matrix have not been violated. The Eigenvalues for each of the five personality trait components were also greater than one (1) indicating that they constitute valid and important explanatory variables (Field, 2009 , p. 660). The cumulative percentage of explained variance is $56.69 \%$.

Based on Table IV, the social entrepreneurship components, the Cronbach $\alpha$ values for social entrepreneurship dimensions of social vision and innovation are 0.89 , sustainability and social networks is 0.87 while financial returns is 0.82 . The Cronbach $\alpha$ values of above 0.7 indicates that the constructed scales have high reliability. The KMO test shows a value of 0.89 , and the Bartlett's test of sphericity has a chi-squared value of 3,584 $(\mathrm{df}=528 ; p$ value $=0.01)$ indicating that sample is adequate and suitable for conducting EFA. The Eigenvalues of above one (1) also indicates that the 5 five-dimensions of social entrepreneurship extracted are valid factors. As such, the accompanying findings 
The Influence of Personality Traits and Demographic Factors

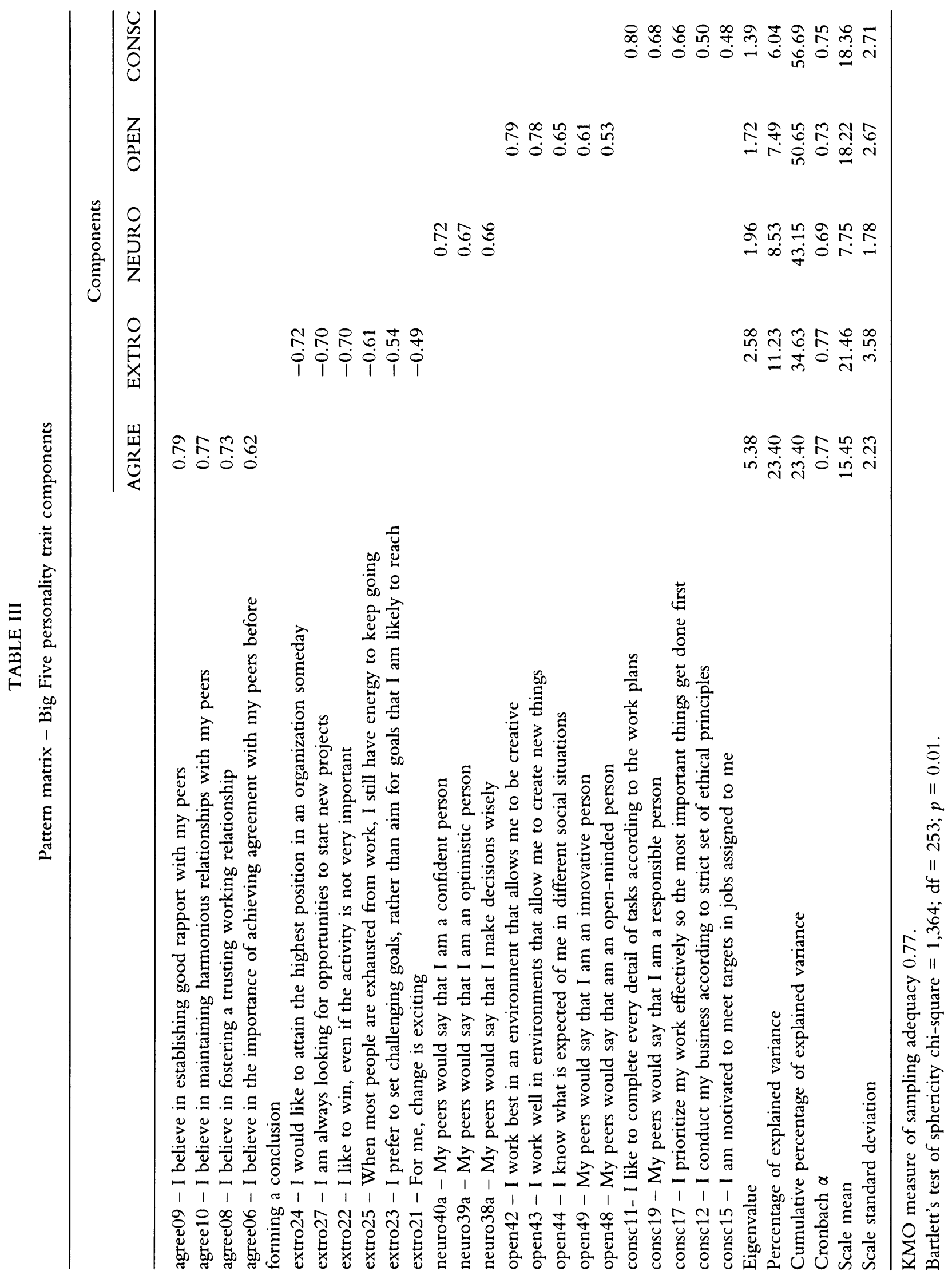




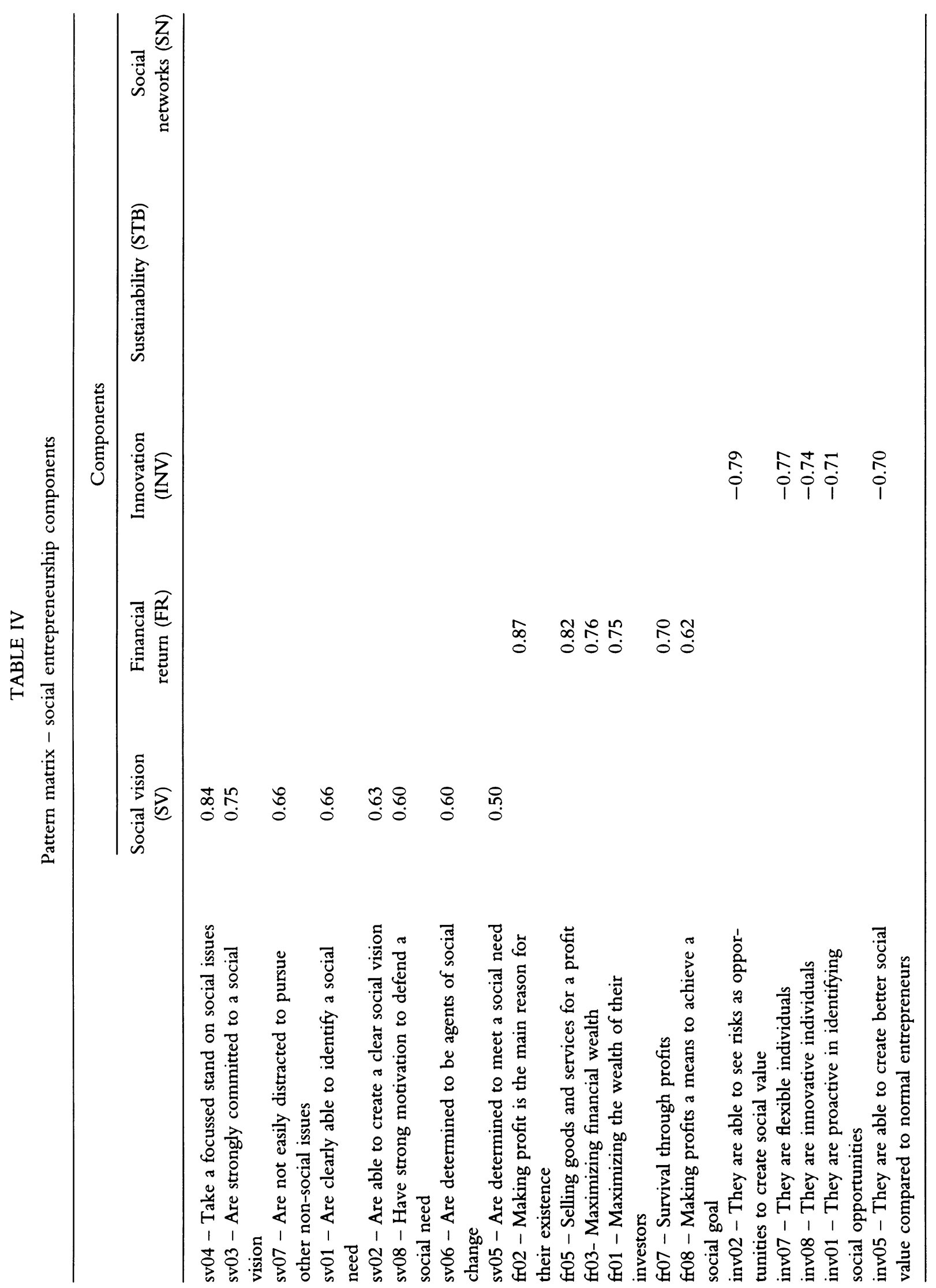


The Influence of Personality Traits and Demographic Factors

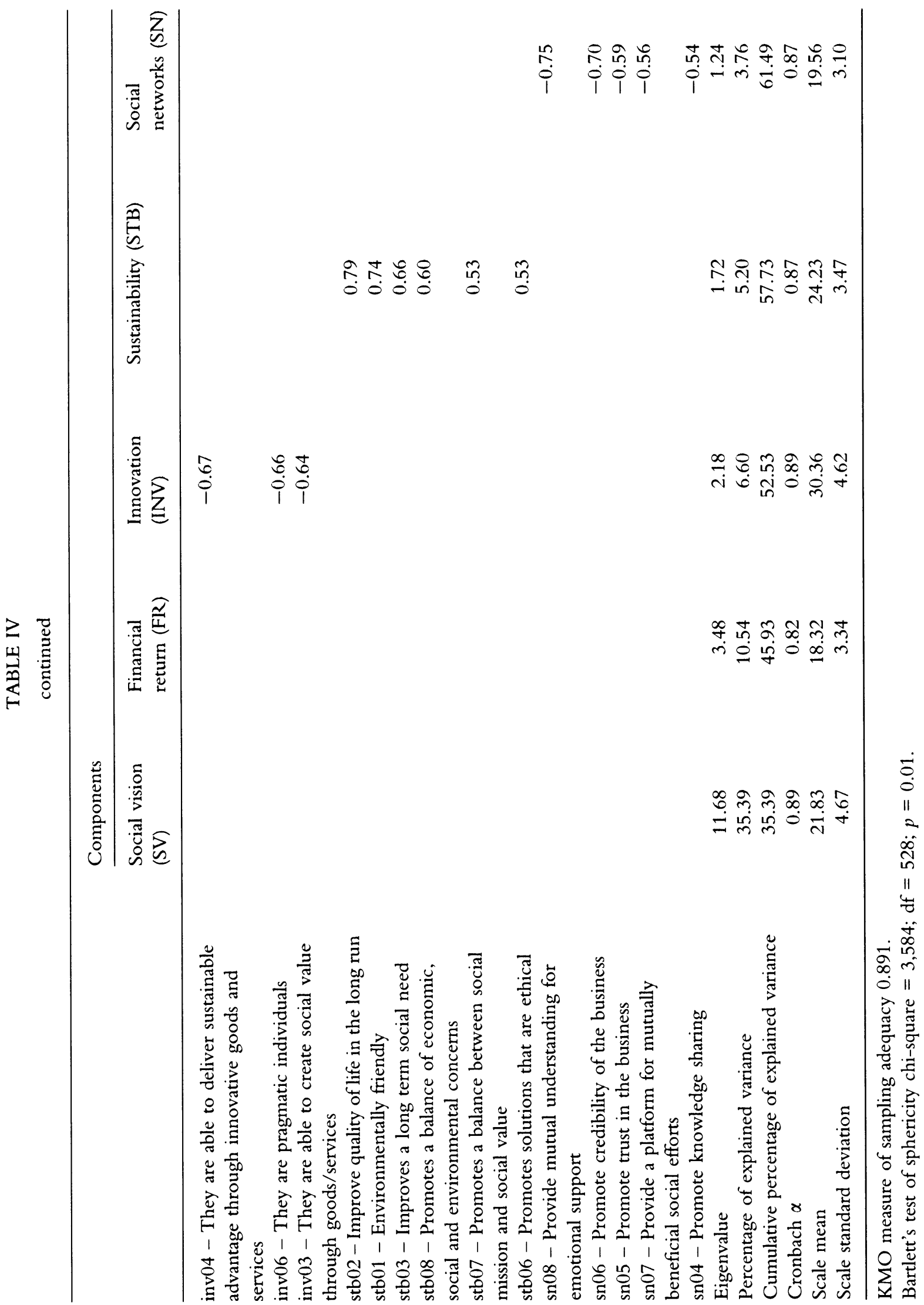


support the establishment of the social entrepreneurship scale as a valid and reliable scale.

The final Strahan-Gerbasi Social Desirability Scale (1972 cited in Thompson and Phua, 2005) comprising seven (7) items recorded a Cronbach $\alpha$ reliability of 0.63 with a scale mean of 22.80 and standard deviation of 3.57. As the Cronbach $\alpha$ lies between the range of 0.60 and 0.70 , reliability can also be assumed (Hair et al., 2006, pp. 137-139).

\section{Hypothesis testing}

The 17 hypotheses (denoted by the $\mathrm{H}_{1}$ to $\mathrm{H}_{5}$ series) have been tested by employing multiple linear regression (MLR) method. The social entrepreneurship dimensions of social vision (SV), sustainability (STB), social networks (SN), innovation (INV) and financial returns (FR) are treated as dependent variables. The independent variables are represented by the Big Five personality factors. SDB has been included as an independent control variable. Table $\mathrm{V}$ below tabulates the results of the hypothesis testing. Assumptions of normality of the residuals of the dependent variables have been satisfied for all the hypotheses.

Based on Table $\mathrm{V}$, hypotheses $\mathrm{H}_{1(\mathrm{a})}$ to $\mathrm{H}_{1(\mathrm{c})}$ are supported at the 0.05 significance level. As such, openness (OPEN) exerts an influence on SV, STB and FR. Similarly, for agreeableness (AGREE), hypotheses $\mathrm{H}_{3(\mathrm{a})}$ to $\mathrm{H} 3(\mathrm{e})$ are supported. Thus, AGREE exerts a significant influence on all four dimensions of social entrepreneurship. The relevant hypotheses related to conscientiousness (CONSC), $\mathrm{H}_{4(\mathrm{a})}$ and $\mathrm{H}_{4(\mathrm{~b})}$ are also supported indicating that CONSC has a significant influence on STB and FR. As for neuroticism (NEURO), only $\mathrm{H}_{5(\mathrm{~b})}$ is supported implying that NEURO exerts a negative relationship on the fostering of social networks. Table $\mathrm{V}$ also shows that the control variable SDB did not exert any statistically significant influence on the responses in this study except for FR. The adjusted $R^{2}$ in all the regression models range from 0.096 to 0.262 indicating that the population effect size is medium to large (Cohen, 1992).

\section{Discussion and implications}

The findings of this study suggest that certain personality traits such as agreeableness, openness and

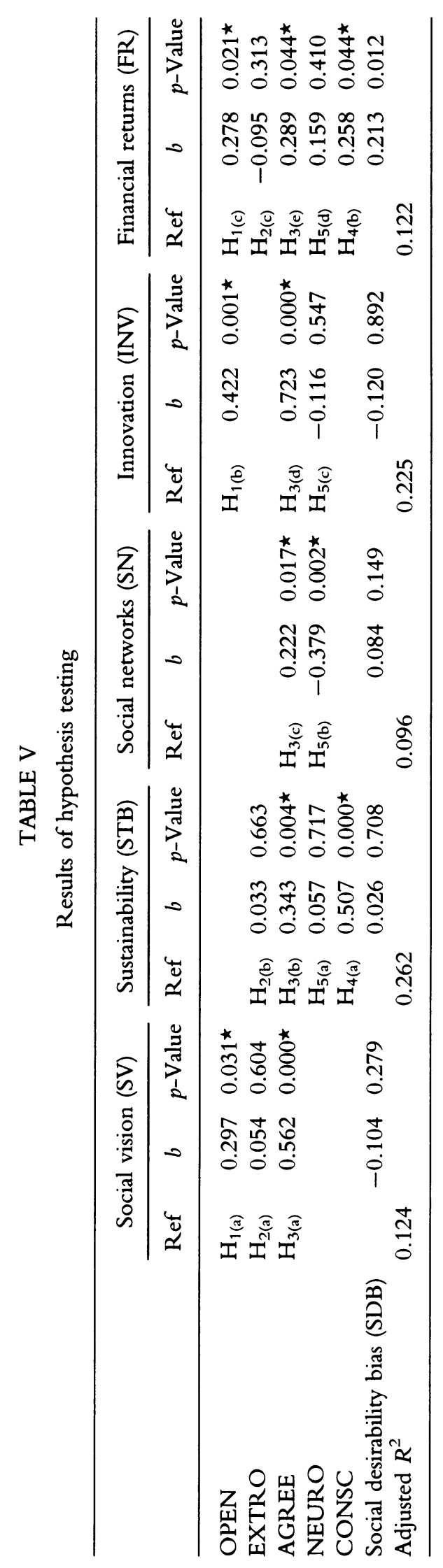


conscientiousness exert an influence on social entrepreneurship dimensions. The following section discusses how we can develop the business and management education curriculum further to enhance awareness, understanding and development of social responsibility and the requisite personality traits above through character education. The implication of how the development of character and social entrepreneurship can be inculcated through student-centred learning and life-long learning is also further discussed below.

\section{Social responsibility}

The study findings reveal that agreeableness is the only personality trait that exerts significant influence across all dimensions of social entrepreneurship. As such in a multi-racial nation such as Malaysia, the education curriculum needs to promote constructive dialogue to encourage better understanding on multicultural values and perspectives. Students have to appreciate their role as future leaders within an ecosystem comprising businesses, society and the environment. Internalization of the interconnectedness of economic, social and environmental concerns requires continual reflective learning reinforcements across different disciplines of academia to promote holistic grasps of the principles of sustainability (Warburton, 2003). Within this context, collaborative efforts between academic institutions, corporations and society are required to provide input towards a more comprehensive education system that addresses the relevant modus operandi for sustainable development (Springett and Kearins, 2001). Agreeableness through social consensus between the Education Ministry, NGOs and the private sector may foster healthy appreciation for differing stakeholder views and in deriving a more holistic, dynamic and relevant business education curriculum (Rae, 2009).

The study also found that openness exerted significant positive influence on financial returns and social vision. Conscientiousness was found to exert a positive influence on sustainability and financial returns. The findings imply that social entrepreneurship upholds the compelling values within the social mission in the quest towards long-term social value. In many instances, the personal and corporate/ mutual goals of the entrepreneur are inseparable (London, 2008; Rae, 2009). Thus, the education curriculum needs to be robust in nourishing the desire to create a more sustainable, just and compassionate world (Johnson, 2005). Engagement of students in social issues can be encouraged to enhance motivation, increase critical awareness (Warbuton, 2003) and relevance of social entrepreneurship. Fostering awareness and nurturing them in recognizing their place as global citizens are necessary to equip them to cope with global pressures for sustainable development (Newport et al., 2003). The role of students as empowered future catalyst for social change has to be continually reinforced throughout the curricula (Henle, 2006; Johnson, 2005).

Higher education institutions in Malaysia need to lead in developing cogent global sustainability practices and principles giving a balanced emphasis to the economic, environmental and social concerns (Newport et al., 2003). The appreciation and stance of the academia towards doing its part alleviating global issues such as global warming, security, human rights, poverty and other sustainability concerns are crucial in bridging the gap in academic content and extracting global relevance.

\section{Student centred learning}

This study also found that personality traits of openness and agreeableness exerted a positive influence on social vision construction. Agreeableness and conscientiousness also had a significant and positive influence on the sustainability dimension. Development of sustainability and entrepreneurial traits are driven by personal values/beliefs, experiences and interest beliefs (Barendsen and Gardner, 2004; Krueger Jr., 2007; Warbuton, 2003). Thus, the competence of students to learn how to learn and identify their potential role and contribution towards society (Krueger Jr., 2007) is both a personal and corporate journey. The social entrepreneurial mindset invokes the need for openness in the construction of meaning within the complex business environment involving the internal deliberation of personal values/beliefs and social concerns while making business sense. As such, entrepreneurship education curriculum in HEI need to nurture 
independent learners who are able to develop the competence to construct meaning through concepts, discovery and reflection. Personality traits of openness and agreeableness can also be inculcated via active, problem-based and cooperative learning as students grapple with real-life examples within different social context (Richardson and Hynes, 2008).

\section{Life-long learning}

An individual's aspirations and values/beliefs may evolve through socialization and personal experience gained in the journey of one's career. Thus, personality traits may also be transformed over time (Mezirow, 2008). Life-long learning involves a combination of tacit and explicit knowledge and recognizes the individual as an active creator of meaning in bridging theory and practice (Jørgensen, 2004). Continuous learning takes place as one constantly applies acquired skills, social networks and experience as practical reinforcements to create and/ or capitalize on opportunities in a competitive business environment. Older individuals have been found to have a greater propensity to embark on entrepreneurship compared to younger individuals (Arenius and Minniti, 2005; Beugelsdijk and Noorderhaven, 2005; Walker and Webster, 2007; Weber and Schaper, 2004). Entrepreneurial tendencies are higher among older individuals as they are financially stable in terms of resources, and have greater experience but may be less educated and have less choice of employment. Thus, they may be 'pushed' into self-employment due to lack of alternatives. However, younger individuals are often 'pulled' or lured by greater choices of employment due to their higher financial, family commitments and educational qualifications. As such, there may be a place for adult entrepreneurship education to buttress the knowledge competence in bridging the gap between the current employment status and identity with long-term personal aspiration in making midlife self-employment transitions (Rae, 2005).

Besides technical know-how, life-long learning also incorporates active citizenship which includes the reflection on how an individual sees one's role within the larger society (Leader, 2003). Thus, for life-long business curricula to be relevant in developing responsible citizens, a closely knit chain of engagement staring from parents, educators and organizational leaders are necessary (Packer and Sharrar, 2003). Citizenship within the context of social entrepreneurship, the individual may, as a response to life-long learning, consider social responsibility as a good opportunity to ameliorate one's intrinsic social vision within other personal goals.

\section{Character education}

Character education may have a bearing in the development of conscientiousness which has been found to positively influence sustainability and financial returns in this study. The twofold thrust of character education relates to the development of personal and relationship virtues (Benninga, et al., 2006). Personal virtues include development of conscientiousness, self-resolve, courage to exert one's intellectual voice, exercise of responsibility, honesty, hope and humility (Rivers, 2004). On the other hand, relationship virtues relate to issues surrounding social interaction and integration, for instance, respect, tolerance, equitable practices and tolerance. As such, relationship virtues may promote practical agreement through reasonable compromise within legal and moral confines.

Character education may also mitigate the resistance to change arising from false social perceptions between different groups of peoples. Students are continually challenged to evaluate and deliberate on the essence of a decision or situation on its own merits rather than passing simple 'right' or 'wrong' judgement. In so doing, students learn to develop openness via tolerate a diversity of views and learn to act responsibly despite the contingencies in the situation (Benninga et al., 2006; Polan, 1991). As such, character education provides the foundations for citizenship education which attempts to develop a sense of moral and social/civic convictions through critical reflection and engagement (Gilness, 2003; Joseph and Efron, 2005; Polan, 1991). Character education may indirectly contribute towards the inculcation of one's moral and social intelligence (Landy, 2005; Lennick and Kiel, 2005, p. 7; Silberman, 2001; Strang, 1930). In certain instances, character education has also been found to improve academic achievement (Benninga et al., 2006). As 
moral and social virtues permeate human interaction in all areas of business, character education promulgation requires interdisciplinary reinforcements Joseph and Efron, 2005; Polan, 1991; Rivers, 2004).

\section{Entrepreneurship education}

Social and commercial entrepreneurs share certain similar characteristics such as affinity towards risktaking, creativity and opportunism (Kirby, 2004; Mort et al., 2003). As such, entrepreneurship education needs to promote a proper balance of rational thought rooted in technical knowledge base and intuitive thinking (Kirby, 2004). Student-centred learning approaches such as cooperative and problem-based learning can be employed to increase the relevance of the curriculum and to encourage students to take ownership of their learning. The experience gained by involving students working in teams in solving simulations of real-life issues will develop the ability to endure the uncertainty in a business environment enveloped by constant change. Teamwork also establishes potential social and business networking opportunities (Collins et al., 2004).

\section{Sustainability education}

Social entrepreneurship education needs to include a firm grounding on ethics and sustainable practices. A sustainability education curriculum needs to encourage greater research, deep reflection and discussions on ways to better achieve equitable balance of economic, social and environmental development (Campbell and Dealtry, 2003). Human exploitation of the environmental resources needs to be carefully weighed against the regenerative capability of the ecosystem (Birch, 2008). Future leaders need to consciously consider the pivotal role corporations play in preserving the equilibrium of the socioeconomic and environmental ecosystem. Sustainability needs to be treated as an interdisciplinary discipline which is required integrated emphasis across all core business courses taught at institutions of higher learning to reinforce its multi-faceted meaning and applications (Stubbs and Cocklin, 2008; Thomas, 2004; Velazquez et al., 2005). In addition, future business executives need moral courage to be leaders of transformation by embracing sustainability into the soul of the business by committing to be global citizens (Birch, 2008).

\section{Limitations and further research}

This study is an initial study on personality traits and social entrepreneurship based on concepts derived from literature. The study was undertaken with an understanding that undergraduate students can be skilfully trained and motivated to engage in socially entrepreneurial activities (Bull, 2008). The objective aim is to highlight areas where social entrepreneurship and associated personality traits could be incorporated in business and management education curriculum.

However, the scope of this study is limited to undergraduate students. The quantitative survey method may also lack the depth in explanation of the dilemmas and challenges that social entrepreneurs face in reality. As such, separate qualitative research on the practitioners' viewpoint using case study methods to understand is suggested. Qualitative findings may also complement and deepen our understanding of how personalities cum character of social entrepreneurs are moulded. The insight gained can then be used to refine the conceptual framework that applies to working adults as well as further reinforce relevance of business and management education curricula.

Future studies may also need to control the effect of socio-economic factors and demographics beyond personality traits on the intention to pursue social entrepreneurship.

\section{Conclusion}

Social entrepreneurship is emerging as a sustainable solution in integrating financial/economic interest and social value. This unity of purpose is upheld by the overarching vision that commits to a social dimension to business decisions. This study has found that personality traits such as agreeableness, openness and conscientiousness have generally a positive influence on social entrepreneurship dimensions. In particular, agreeableness has been found to have a 
positive influence across all social entrepreneurship dimensions investigated, namely social vision, innovation, sustainability, social networking and financial returns. As such, there is a need to inculcate these personality traits among business students to promote greater social entrepreneurial spirit through engagement, awareness of social responsibility, creativity reflective learning and good character development. Social entrepreneurship requires the combination of head knowledge and heart virtues that fosters the courage to become catalysts of change while undertaking opportunities that offer an enhanced blend of economic, social cum environmental value.

\section{References}

Abd Moen, J., I. Abd Rahman, M. F. Md Salleh and R. Ibrahim: 2004, 'A Study on Entrepreneurial Attitudes Among Youths in Malaysia. Case Study: Institute Kemahiran Belia Negara Malaysia', Journal of American Academy of Business 4(1/2), 192-197.

Abu Elanain, H. M.: 2008, 'An Investigation of Relationship of Openness to Experience and Organizational Citizenship Behaviour', Joumal of American Academy of Business 13(1), 72-78.

Andanda, P.: 2005, 'Module Two: Informed Consent', Developing World Bioethics 5(1), 14-29.

Anderson, A. R.: 1998, 'Cultivating the Garden of Eden: Environmental Entrepreneuring', Journal of Organizational Change Management 11(2), 135-144.

Arenius, P. and M. Minniti: 2005, 'Perceptual Variables amd Nascent Entrepreneurship', Small Business Economics 24, 233-247.

Auersweld, P.: 2009, 'Creating Social Value', Stanford Social Innovation Review 7(2), 51-55.

Austin, J., H. Stevenson and J. Wei-Skillern: 2006, 'Social and Commercial Entrepreneurship: Same, Different or Both?', Entrepreneurship Theory and Practice 30(1), 1-22.

Barendsen, L. and H. Gardner: 2004, 'Is the Social Entrepreneur a New Type of Leader?', Leader to Leader 34, 43-50.

Baumol, W. J.: 1968, 'Entrepreneurship in Economic Theory', The American Economic Revieu 58(2), 64-71.

Benninga, J. S., M. W. Berkowitz, P. Kuehn and K. Smith: 2006, 'Character and Academics: What Good Schools Do’, Phi Delta Kappan 87(6), 448-452.

Beugelsdijk, S. and N. Noorderhaven: 2005, 'Personality Characteristics of Self-Employed: An Empirical Study', Small Business Economics 35, 159-167.
Birch, D.: 2008, 'Working and Fighting for Progress, for Prosperity, for Society: Brave New Business Worlds Before and Beyond Corporate Citizenship', Journal of Corporate Citizenship 29, 25-32.

Brooks, A. C.: 2009, Social Entrepreneurship: A Modern Approach to Social Venture Creation, Person International Edition, New Jersey.

Bryman, A. and E. Bell: 2007, Business Research Methods, 2nd Edition (Oxford University Press, New York).

Bull, M.: 2008, 'Challenging Tensions: Critical, Theoretical and Empirical Perspectives on Social Enterprise', Intemational Journal of Entrepreneurial Behaviour and Research 14(5), 268-275.

Caliendo, M. and A. S. Kritikos: 2008, 'Is Entrepreneurial Success Predictable? An Ex-ante Analysis of the Character-Based Approach', Kyklos 61(2), 189-214.

Campbell, I. and R. Dealtry: 2003, 'The New Generation of Corporate Universities: Co-Creating Sustainable Enterprise and Business Development Solutions', Journal of Workplace Learning 13(7/8), 368-381.

Cartwright, W. and J. L. Craig: 2006, 'Sustainability: Aligning Corporate Governance, Strategy and Operations with the Planet', Business Process Management 12(6), 741-750.

Cavana, R. Y., B. L. Delahaye and U. Sekaran: 2000, Applied Business Research: Quantitative and Qualitative Methods (John Wiley \& Sons, Australia).

Chaucin, B., D. Hermand and E. Mullet: 2007, 'Risk Perception and Personality Facets', Risk Analysis 27(1), 171-185.

Chen, M. and M. Wang: 2008, 'Social Networks and a New Venture's Innovative Capability: The Role of Trust Within Entrepreneurial Teams', $R E D$ Management 38(3), 253-263.

Ciavarella, M. A., A. K. Buchholtz, C. M. Riodan, R. D. Gatewood and G. S. Stokes: 2004, 'The Big Five and Venture Capital Survival', Joumal of Business Venturing 19, 465-483.

Cohen, J.: 1992, 'Quantitative Methods in Psychology: A Power Primer', Psychological Bulletin 112(1), 155159.

Collins, L., P. D. Hannon and A. Smith: 2004, 'Enacting Entrepreneurial Intent: The Gaps Between Student Needs and Higher Education Capability', Education + Training 46(8/9), 454-463.

Cools, E. and H. Van den Broeck: 2008, 'The Hunt for the Heffalump Continues: Can Trait and Cognitive Characteristics Predict Entrepreneurial Orientation?', Journal of Small Business Strategy 18(2), 23-41.

Cope, J.: 2005, 'Toward a Dynamic Learning Perspective of Entrepreneurship', Entrepreneurship Theory and Practice 27(2), 93-104. 
Crane, F. G. and E. C. Crane: 2007, 'Sispositional Optimism and Entrepreneurial Success', The Psychologist-Manager Journal 10(1), 13-25.

Crant, J. M.: 1996, 'The Proactive Personality Scale as a Predictor of Entrepreneurial Intentions', Journal of Small Business Management 34(1), 42-49.

D'Intino, R. S., M. G. Goldsby, J. D. Houghton and C. P. Neck: 2007, 'Self Leadership: A Process for Entrepreneurial Success', Journal of Leadership \& Organizational Studies 13(4), 105-120.

De Carolis, D. M. and P. Saparito: 2006, 'Social Capital, Cognition and Entrepreneurial Opportunities: A Theoretical Framework', Entrepreneurship Theory and Practice 30(1), 41-56.

Dees, J. G.: 2001, The Meaning of Social Entrepreneurship. http://www.fuqua.duke.edu/centers/case/ documents/dees_SE.pdf. Accessed 25 June 2008.

Dees, J. G.: 2007, 'Taking Social Entrepreneurship Seriously', Society 44(3), 24-31.

Elkington, P.: 2006, 'It's About People, Not Profits', Business Strategy Revieu' Winter issue, 43-45.

Elkington, J. and P. Hartigan: 2008, The Power of Unreasonable People (Harvard Business Press, USA).

Field, A.: 2009, Discovering Statistics Using SPSS, 3rd Edition (Sage Publication, London).

Flick, U.: 2009, An Introduction to Qualitative Research, 4th Edition (Sage Publication, London).

Frank, H., M. Lueger and C. Korunka: 2007, 'The Significance of Personality in Business Start-up Intentions, Start-up Realization and Business Success', Entrepreneurship \& Regional Development 19, 227-251.

Gilness, J.: 2003, 'How to Integrate Character Education into the Curriculum', Phi Delta Kappan 85(3), 243245.

Gliedt, T. and P. Parker: 2007, 'Green Community Entrepreneurship: Creative Destruction in the Social Economy', International Journal of Social Economics 34(8), 538-553.

Goss, D.: 2005, 'Schumpeter's Legacy?: Interaction and Emotions in the Sociology of Entrepreneurship', Entrepreneurship Theory and Practice 29(2), 205-218.

Goss, D.: 2008, 'Enterprise Ritual: A Theory of Entrepreneurial Emotion and Exchange', British Journal of Management 19, 120-137.

Greve, A. and J. W. Salaff: 2003, 'Social Networks and Entrepreneurship', Entrepreneurship Theory and Practice 28(1), 1-22.

Gunn, R., C. Durkin, G. Singh and J. Brown: 2008, 'Social Entrepreneurship in the Social Policy Curriculum', Social Enterprise Journal 4(1), 74-80.

Hair, J. F., W. C. Black, B. J. Babin, R. E. Anderson and R. L. Tatham: 2006, Multivariate Data Analysis, 6th Edition (Pearson Education International, USA).
Handy, F., B. Ranade and M. Kassam: 2007, 'To Profit or Not to Profit: Women Entrepreneurs in India', Nonprofit Management and Leadership 17(4), 383-401.

Hart, S. L.: 2005, 'Innovation, Creative Destruction and Sustainability', Research Technology Management 45(5), 21-33.

Hart, S. L. and C. M. Christensen: 1992, 'The Great Leap: Driving Innovation From the Base of the Pyramid', MIT Sloan Management Revieu 44(1), 51-56.

Hart, S. L. and T. London: 2005, 'Developing Native Capability: What Multinational Corporations Can Learn From the Base of the Pyramid', Stanford Social Innovation Review 3(2), 28-33.

Haughton, C.: 2008, 'The Edge of Reason', Director 61(7), 70-74.

Hawken, P.: 1992, 'The Ecology of Commerce', Inc., Vol. 14(4), pp. 93-100.

Henle, C. A.: 2006, 'Bad Apples or Bad Barrels? A Former CEO Discusses the Interplay of Person and Situation with Implications for Business Education', Academy of Management Learning E Education 5(3), 346355.

Homan, R.: 2001, 'The Principle of Assumed Consent: The Ethics of Gatekeeping', Journal of Philosophy of Education 35(3), 329-343.

Jayasinghe, K., D. Thomas and D. Wickramasinghe: 2008, 'Bounded Emotionality in Entrepreneurship: An Alternative Framework', International Journal of Entrepreneurial Behaviour E Research 14(4), 242-258.

Johnson, B.: 2005, 'Overcoming "Doom and Gloom": Empowering Students in Courses on Social Problems, Injustice and Inequality', Teaching Sociology 33(1), 4458.

Jørgensen, C. H.: 2004, 'Connecting Work and Education: Should Learning be Useful, Correct or Meaningful?', The Journal of Workplace Learning 16(8), 455465.

Joseph, P. B. and S. Efron: 2005, 'Seven Worlds of Moral Education', Phi Delta Kappan 86(7), 525-533.

Keogh, P. D. and M. J. Polonsky: 1998, 'Environmental Commitment: A Basis for Environmental Entrepreneurship?', Journal of Organizational Change Management 11(1), 38-49.

King, M. F. and G. C. Brunner: 2000, 'Social Desirability Bias: A Neglected Aspect of Validity Testing', Psychology and Marketing 17(2), 79-103.

Kirby, D. A.: 2004, 'Entrepreneurship Education: Can Business Schools Meet the Challenge?', Education Training 46(8/9), 510-519.

Kor, Y. Y., J. T. Mahoney and S. C. Micheal: 2007, 'Resources, Capabilities and Entrepreneurial Perception', Joumal of Management Studies 44(7), 11871212. 
Krueger, N. F. Jr: 2007, 'What Lies Beneath? The Experiential Essence of Entrepreneurial Thinking', Entrepreneurship Theory E Practice 31(3), 123-137.

Kurucz, E. C., B. A. Colbert and D. C. Wheeler: 2008, 'The Business Case for Corporate Social Responsibility', in A. Crane, A. McWilliams, D. Matten, J. Moon and D. Seigel (eds.), The Oxford Handbook on Corporate Social Responsibility (Oxford University Press, Oxford, In Press: March 2008).

Landy, F. J.: 2005, 'Some Historical and Scientific Issues Related to Research on Emotional Intelligence', Journal of Organizational Behaviour 26, 411-424.

Leader, G.: 2003, 'Lifelong Learning: Policy and Practice in Further Education', Education + Training 45(7), 361-370.

Leisinger, K. M.: 2007, 'Corporate Philanthropy: The "Top of the Pyramid"', Business and Society Revieu" 112(3), 315-342.

Lennick, D. and F. Kiel: 2005, Moral Intelligence: Enhancing Business Performance $\mathcal{E}$ Leadership Success (Wharton School Publishing, USA).

Littunen, H.: 2000, 'Entrepreneurship and the Characteristics of the Entrepreneurial Personality', International Journal of Entrepreneurial Behaviour \& Research 6(6), 295-309.

Llewellyn, D. J. and K. M. Wilson: 2003, 'The Controversial Role of Personality Traits in Entrepreneurial Psychology', Education + Training 45(6), 341-345.

Loasby, B. J.: 2007, 'A Cognitive Perspective on Entrepreneurship and the Firm', Journal of Management Studies 44(7), 1078-1106.

London, M.: 2008, 'Dual Roles for Corporate Social Responsibility and Social Entrepreneurship', Organizational Dynamics 37(4), 313-326.

Lovins, A. B., L. H. Lovins and P. Hawken: 2007, 'A Road to Natural Capitalism', Harvard Business Review, Jul/Aug, 172-183.

Machan, T. R.: 1999, 'Entrepreneurship and Ethics', International Journal of Social Economics 26(5), 596-608.

Matlay, H.: 2008, 'The Impact of Entrepreneurship Education on Entrepreneurial Outcomes', Journal of Small Business and Enterprise Development 15(2), 382396.

McCarthy, B.: 2003, 'Strategy is Personality Driven, Strategy is Crisis Driven: Insights From Entrepreneurial Firms', Management Decisions 41(4), 327-339.

Mezirow, J.: 2008, 'An Overview of Transformative Learning', in P. Sutherland and J. Crowther (eds.), Lifelong Learning: Concepts and Contexts (Routledge, London), pp. 24-38.

Miles, M. B. and A. M. Huberman: 1994, An Expanded Sourcebook: Qualitative Data Analysis, 2nd Edition (Sage Publication, Thousand Oaks, CA).
Mitchell, R. K., L. Busenitz, T. Lant, P. P. McDougall, E. A. Morse and J. B. Smith: 2002, 'Toward a Theory of Entrepreneurial Cognition: Rethinking the People Side of Entrepreneurial Research', Entrepreneurship Theory and Practice 27(2), 93-104.

Molteni, M.: 2006, 'The Social-Competitive Innovation Pyramid', Corporate Governance 6(4), 516-526.

Mort, G. S., J. Weerawardena and K. Carnegie: 2003, 'Social Entrepreneurship: Towards Conceptualisation', International Journal of Nonprofit and Voluntary Sector Marketing 8(1), 76-88.

Mustakova-Possardt, E.: 1998, 'Critical Consciousness: An Alternative Pathway for Positive Personal and Social Development', Journal of Adult Development 5(1), 13-30.

Naffziger, D. W., J. S. Hornsby and D. F. Kuratko: 1994, 'A Proposed Research Model of Entrepreneurial Motivation', Entrepreneurship Theory E Practice 18(3), 29-42.

Nahapiet, J. and S. Ghoshal: 1998, 'Social Capital, Intellectual Capital and the Organizational Advantage', The Academy of Management Revieu 23(2), 242-266.

Newport, D., T. Chesnes and A. Lindner: 2003, 'The "Environmental" Sustainability Problem: Ensuring That Sustainability Stands on Three Legs', Intermational Journal of Sustainability in Higher Education 4(4), 357363.

Nordvik, H. and H. Brovold: 1998, 'Personality Traits in Leadership Tasks', Scandinavian Joumal of Psychology 39, 61-64.

Ong, J. W. and H. Ismail: 2008, 'Revisiting Personality Traits in Entrepreneurship Study From a Resource Based Perspective', Business Renaissance Quarterly 3(1), 97-114.

Packer, A. H. and G. K. Sharrar: 2003, 'Linking Lifelong Learning, Corporate Social Responsibility and the Changing Nature of Work', Advances in Developing Human Resources 5(3), 332-340.

Peterson, R. A.: 1994, 'A Meta-Analysis of Cronbach's Coefficient Alpha', Joumal of Consumer Research 21(2), 381-391.

Phills, J. A., K. Deiglmeier and D. T. Miller: 2008, 'Rediscovering Social Innovation', Stanford Social Innovation Review 6(4), 34-43.

Pittaway, L.: 2005, 'Philosophies in Entrepreneurship: A Focus on Economic Theories', International Journal of Entrepreneurial Behaviour \& Research 11(3), 201-221.

Polan, A. J.: 1991, 'Personal and Social Education: Citizenship and Biography', Journal of Moral Education 20(1), 13-32.

Pralahad, C. K.: 2006, The Fortune at the Bottom of the Pyramid: Eradicating Poverty Through Profits (Wharton Business School Publishing, USA). 
Rae, D.: 2005, 'Mid-career Entrepreneurial Learning', Education + Training 47(8/9), 562-574.

Rae, D.: 2009, 'Entrepreneurship: Too Risky to Let Loose in a Stormy Climate?', Entrepreneurship and Innovation 10(2), 137-147.

Randall, D. M. and M. F. Fernandes: 1991, 'The Social Desirability Bias in Ethics Research', Journal of Business Ethics 10, 805-817.

Raposo, M., A. do Paco and J. Farreira: 2008, 'Entrepreneur's Profile: A Taxonomy of Attributes and Motivations of University Students', Journal of Small Business and Enterprise Development 15(2), 405418.

Rauch, A. and M. Frese: 2007, 'Let's Put the Person Back into Entrepreneurship Research: A Meta-Analysis on the Relationship Between Business Owners' Personality Traits, Business Creation and Business Success', European Journal of Work and Organizational Psychology 16(4), 353-385.

Rhee, K. S. and R. J. White: 2007, 'The Emotional Intelligence of Entrepreneurs', Journal of Small Business Entrepreneurship 20(4), 409-426.

Richardson, I. and B. And Hynes: 2008, 'Entrepreneurship Education: Towards and Industry Sector Approach', Education + Training 50(3), 188-198.

Ridley-Duff, R.: 2008, 'Social Enterprise as a Socially Rational Business', International Journal of Entrepreneurial Behaviour E Research 14(5), 291-312.

Rivers, T. M.: 2004, 'Ten Essentials for Character Education', The Journal of General Education 3/4(53), 247260.

Robin, F.: 2006, 'The Challenge of TBL: A Responsibility to Whom?', Business and Society 111(1), 1-14.

Sarros, J. C., B. K. Cooper and A. M. Hartican: 2006, 'Leadership and Character', Leadership and Organization Development Journal 27(8), 682-699.

Savitz, A. W. and K. Weber: 2006, The Triple Bottom Line (Jossey-Bass, USA).

Schaefer, B. P.: 2008, 'Shareholders and Social Responsibility', Journal of Business Ethics 81, 297-312.

Schaper, M. and T. Volery: 2004, Entrepreneurship and Small Business: A Pacific Rim Perspective (John Wiley and Sons, Australia).

Schmit, M. J., J. A. Kihm and C. Robie: 2000, 'Development of a Global Measure of Personality', Personnel Psychology 53, 153-193.

Schmitt-Rodermund, E.: 2004, 'Pathways to Successful Entrepreneurship: Parenting, Personality, Early Entrepreneurial Competence and Interest', Journal of Vocational Behaviour 65, 498-518.

Shane, S. and D. Cable: 2002, 'Network Ties, Reputation and Financing of New Ventures', Management Science 48(3), 364-381.
Shaw, E. and S. Carter: 2007, 'Social Entrepreneurship: Theoretical antecedents and Empirical Analysis of the Entrepreneurial Processes and Outcomes', Journal of Small Business and Economic Development 14(13), 418434.

Silberman, M.: 2001, 'Developing Interpersonal Intelligence in the Workplace', International and Commercial Training 7(5), 266-269.

Springett, D. and K. Kearins: 2001, 'Gaining Legitimacy?', Sustainable Development in Business School Curricula 9(4), 213-221.

Strang, R.: 1930, 'Measures of Social Intelligence', The American Journal of Sociology 36(2), 263-269.

Stubbs, W. and C. Cocklin: 2008, 'Teaching Sustainability to Business Students: Shifting Mindsets', International Journal of Sustainability in Higher Education 9(3), 206-221.

Thomas, I.: 2004, 'Sustainability in Tertiary Curricula: What is Stopping it Happening?', International Journal of Sustainability in Higher Education 5(1), 33-47.

Thompson, J. L.: 1998, 'A Strategic Perspective of Entrepreneurship', International Journal of Entrepreneurial Behaviour \& Research 5(6), 279-296.

Thompson, J. L.: 2002, 'The World of the Social Entrepreneur', The International Journal of Public Sector Mancrgement 15(5), 412-431.

Thompson, J., G. Alvy and A. Lees: 2000, 'Social Entrepreneurship - A New Look at the People and Potential', Management Decision 38(5), 328-338.

Thompson, L. and B. Doherty: 2006, 'The Diverse World of Social Enterprise: A Collection of Social Enterprise Stories', International Journal of Social Economics 33(5/6), 361-375.

Velazquez, L., N. Munguia and M. Sanchez: 2005, 'Deterring Sustainability in Higher Education Institutions: An Appraisal of The Factors Which Influence Sustainability in Higher Education Institutions', International Journal of Sustainability in Higher Education 6(4), 383-391.

Vinten, G.: 1997, 'The Threat in the Questions', Credit Control 18(1), 25-31.

Walker, E. A. and B. J. Webster: 2007, 'Gender, Age and Self-Employment: Some Things Change, Some Stay the Same', Women in Management Revieu' 22(2), 122135.

Warbuton, K.: 2003, 'Deep Learning and Education for Sustainability', International Journal of Sustainability in Higher Education 4(1), 44-56.

Weber, P. and M. Schaper: 2004, 'Understanding the Grey Entrepreneur', Journal of Enterprising Culture 12(2), 147-167.

Wheeler, D., K. McKague, J. Thomson, R. Davies, J. Medalye and M. Prada: 2005, 'Creating Sustainable 
Local Enterprise Networks', MIT Sloan Management Review 47(1), 38-40.

Wilson, F., J. Kickul and D. Marlino: 2007, 'Gender, Entrepreneurial Self-efficacy and Entrepreneurial Career Intentions: Implications for Entrepreneurial Education', Entrepreneurship Theory and Practice 31(3), 387-406.

Yong, L.: 2007, Emotional Intelligence in the Workplace: Leonard Personality Inventory (LPI) Profiling (Leonard Personality Incorporated, Malaysia).

Yunus, M.: 2007, Creating a World Without Poverty - Social Business and the Future of Capitalism (BBS Public Affairs, USA).

Zhao, H. and S. E. Seibert: 2006, 'The Big Five Personality Dimensions and Entrepreneurial Status: A Meta-Analytical Review', Journal of Applied Psychology 91(2), 259-271.

Joyce Koe Hwee Nga

School of Business, Sunway University College, Selangor Darul Ehsan, Malaysia E-mail: joycen88@gmail.com

Gomathi Shamuganathan Taylor's University College, Selangor Darul Ehsan, Malaysia E-mail: shgomathi@gmail.com 